\title{
PET/CT Imaging of a Rare Presentation of Mantle Cell Lymphoma with Testicular Involvement
}

\author{
Manto Hücreli Lenfomada Nadir Görülen Testiküler Tutulumun PET/CT ile Görüntülenmesi
}

Billur Çalıskan', James Peterson², Robert Henderson²

I Abant Izzet Baysal University Faculty of Medicine, Department of Nuclear Medicine, Bolu, Turkey

2University of Southern California Keck Faculty of Medicine, Department of Radiology, Division of Nuclear Medicine, Los Angeles, USA

\begin{abstract}
In this case, we present F-18 Fluorodeoxglucose (FDG) Positron emission tomography/computed tomography (PET/CT) images of a 72-year-old male with a history of metastatic mantle cell lymphoma (MCL). PET/CT was done as part of treatment planning following chemotherapy. PET/CT demonstrated multiple osseous metastases, multiple cervical and pelvic lymph nodes as well as extranodal disease on bilateral testes, bilateral adrenals, and several subcutaneous soft tissue nodules. MCL is a rare form of non-Hodgkin disease that generally presents with disseminated disease and extranodal involvement. Herein, we presented a very rare case of testicular MCL by PET/CT imaging.
\end{abstract}

Key words: Positron emission tomography/computed tomography, mantle cell lymphoma, testicles

Conflicts of Interest: The authors reported no conflict of interest related to this article.

\section{Özet}

Bu olguda, metastatik manto hücreli lenfoma hikayesi olan 72 yaşındaki erkek hastanın F-18 florodeoksiglukoz Pozitron emisyon tomografi/bilgisayarlı tomografi (PET/BT) görüntülerini sunduk. Kemoterapi alan hastanın bir sonraki tedavi stratejisinin belirlenmesi için PET/BT görüntüleme yapıldı. PET/BT, kemik metastazları, servikal ve pelvik lenf nodu metastazları ile bilateral testiste, bilateral adrenal bezde ve birkaç adet deri altı yumuşak doku nodüllerinde extranodal hastalık tutulumunu gösterdi. Manto hücreli lenfoma non-Hodgkin lenfomanın nadir bir formudur. Genellikle extranodal tutulum ve yaygın hastalık olarak ortaya çıkar. Biz bu olguda manto hücreli lenfomanın çok nadir bir tutulum yeri olan testis tutulumunu PET/ BT görüntüleri ile sunduk.

Anahtar kelimeler: Pozitron emisyon tomografi/bilgisayarlı tomografi, manto hücreli lenfoma, testisler

Çıkar Çatışması: Yazarlar bu makale ile ilgili olarak herhangi bir çıkar çatışması bildirmemiştir.

\section{Introduction}

Mantle cell lymphoma (MCL) accounts for approximately $5 \%$ of all lymphomas. MCL has a male and adult predominance. Generally it presents with disseminated disease, splenomegaly and bone marrow involvement. MCL tends to involve extranodal sites, and the most commonly involved extranodal sites are reported as gastrointestinal tract, Waldeyer's ring, skin, and ocular adnexa. Testicular involvement of $\mathrm{MCL}$ is extremely rare. Few cases were reported in literature but Positron emission tomography/computed tomography (PET/CT) modality wasn't used in any of them $(1,2)$. To the best of our knowledge, this is the first case reporting testicular involvement of $\mathrm{MCL}$ by PET/CT.

Address for Correspondence: Billur Çalışkan MD, Abant İzzet Baysal University Faculty of Medicine, Department of Nuclear Medicine, Bolu, Turkey Phone: +905385468033 E-mail: billurcaliskan@gmail.com Received: 09.11.2013 Accepted: 18.02.2014 


\section{Case Report}

A 72 year-old-male was diagnosed with $\mathrm{MCL}$. He received chemotherapy and underwent PET/CT three months later for subsequent evaluation. PET/CT showed marked progression of lymphomatous disease with extremely high metabolic activity on nodal, osseous and extranodal sites (Figure 1). There was hypermetabolism in the external iliac nodal conglomerate that measured approximately $3.0 \mathrm{~cm} \times 2.3$ $\mathrm{cm}$ in size, with a maximum standardized uptake value (SUVmax) of 57.5 (Figure 2), as well as in the right inguinal nodal chain (Figure 3). In addition, there was evidence of extranodal disease with increased metabolic activity in bilateral testicles (Figure 3), bilateral adrenal glands, and several subcutaneous hypermetabolic soft tissue nodules. The largest subcutaneous soft tissue nodule was within the left buttock, and had a SUVmax of 12.2 (Figure 4). Within a month following PET/CT imaging, core biopsy was performed from the left buttock lesion. Pathology report confirmed the diagnosis of $\mathrm{MCL}$ with a pleomorphic variant.

\section{Literature Review and Discussion}

$\mathrm{MCL}$ is an aggressive sub-type of non-Hodgkin lymphoma. The diagnosis of $\mathrm{MCL}$ includes laboratory findings, lymph node biopsy, bone marrow evaluation, and imaging modalities such as computed tomography and magnetic resonance imaging. FDG PET imaging is also used in all kinds of lymphoma for staging, re-staging, and evaluating response to therapy. It has recently been reported that FDG PET/CT has a high sensitivity in detecting both nodal and extranodal disease in $\operatorname{MCL}(3,4)$.

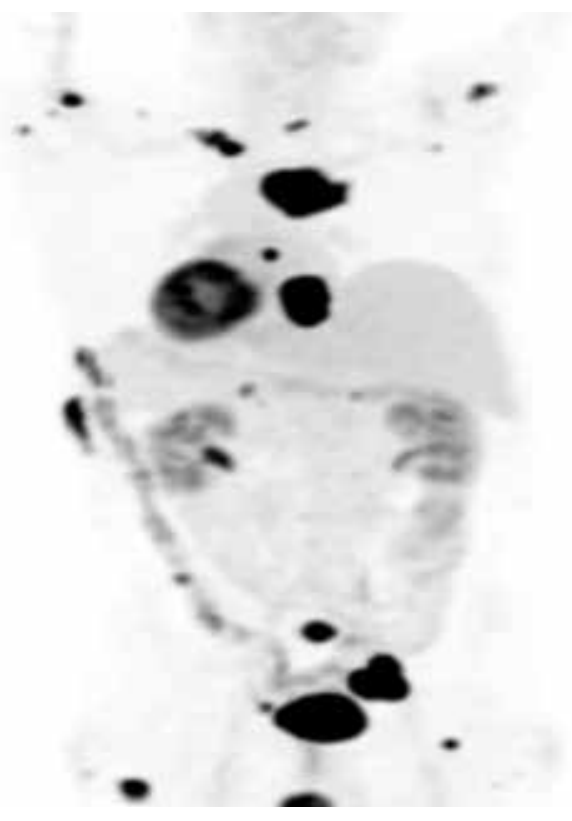

Figure 1. Maximum intensity projection image of PET/CT demonstrated extensive metastatic disease
$\mathrm{MCL}$ tends to involve extranodal sites, especially bone marrow, spleen, gastrointestinal tract, Waldeyer's ring, skin, and ocular adnexa (5). Central nervous system involvement seems to occur in advanced disease, and is very rare (6).

Testicular involvement of MCL has been reported to be extremely rare. Epstein et al. (2) reported testis-isolated $\mathrm{MCL}$ in one case, while Licci et al. (7) described primary MCL of the testis in a patient. To the best of our knowledge, our case is the 8th reported $\mathrm{MCL}$ with testicular involvement, and is the first case which was demonstrated with PET/CT $(1,8,9)$.

In the presented case, we observed a very high FDG avidity in metastatic lesions, for example left iliac lymph node conglomeration had a SUVmax of 57.5. Since some authors suggest that $\mathrm{MCL}$ could transform to a more aggressive form (4), the patient underwent core biopsy. In this case, PET/CT guided the physician to the most suitable and metabolically active site for tissue sampling, and the pathology report confirmed $\mathrm{MCL}$ with a pleomorphic variant.

PET/CT has an advantage of whole-body imaging and guidance for biopsy site in MCL. In this case, PET/ CT demonstrated a very rare involvement of $\mathrm{MCL}$ in the testicles, and aided in clinical management.
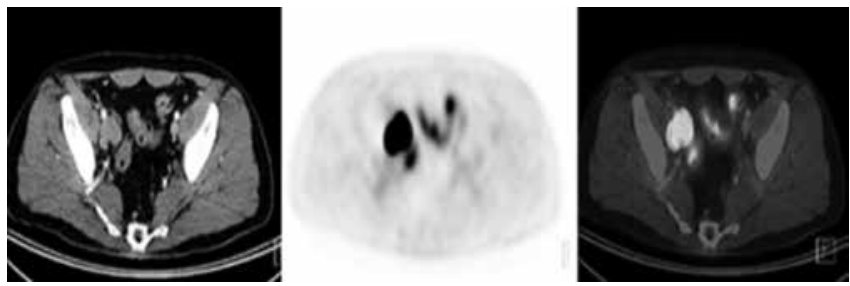

Figure 2. Axial CT, PET and PET/CT fused images showed right iliac nodal mass with a SUVmax of 57.5
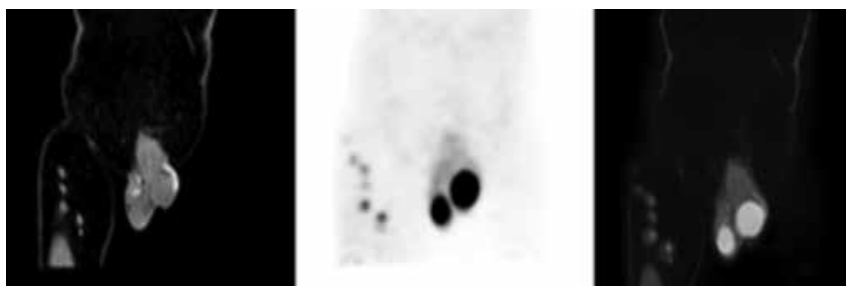

Figure 3. Coronal CT, PET and PET/CT fused images demonstrated increased metabolic activity on both testicles. The right testicle had a SUVmax of 18.1 and the left testicle had a SUVmax of 16.5. The right inguinal nodal chain also had increased metabolic activity
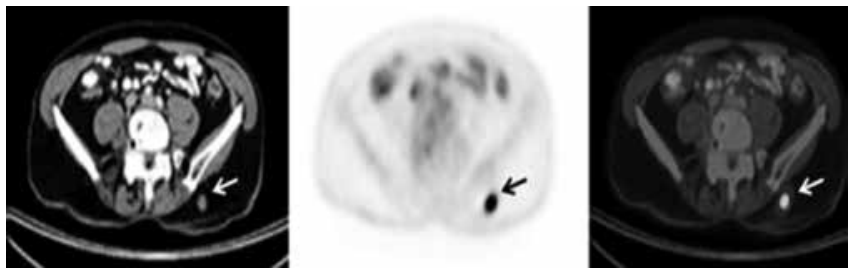

Figure 4. Left subcutaneous buttock lesion is demonstrated by arrows 


\section{References}

1. Iwuanyanwu E, Medeiros LJ, Romaguera JE, Fayad LE. Mantle cell lymphoma with a rare involvement of the testicle. Leuk Lymphoma 2007:48:1242-1243.

2. Epstein A.S, Hedvat C, Habib F, Hamlin P. Testis-isolated mantle cell lymphoma: a unique case. Clin Lymphoma Myeloma Leuk 2011;11:439-441.

3. Alavi A, Shrikanthan S, Aydin A, Talanow R, Schuster S. Fluorodeoxyglucose-positron-emission tomography findings in mantle cell lymphoma. Clin Lymphoma Myeloma Leuk 2011;11:261 266.

4. Brepoels L, Stroobants S, De Wever W, Dierickx D, Vandenberghe P, Thomas J, Mortelmans L, Verhoef G, De Wolf-Peeters C. Positron emission tomography in mantle cell lymphoma. Leuk Lymphoma 2008;49:1693-1701.
5. Ozkan E, Lacin S, Soydal C, Araz M, Kucuk NO. Ocular involvement in mantle cell lymphoma detected by F 18 FDG PET/CT. Mol Imaging Radionucl Ther 2011;20:36-37.

6. Bilici A, Ustalioglu BB, Seker M, Canpolat N, Gumus M. F-18 FDG $\mathrm{PET} / \mathrm{CT}$ imaging in recurrent mantle cell lymphoma presenting with cauda equina syndrome. Clin Nucl Med 2010;35:211-212.

7. Licci S, Morelli L, Covello R. Primary mantle cell lymphoma of the testis. Ann Hematol 2011;90:483-484.

8. Ferry JA, Harris NL, Young RH, Coen J, Zietman A, Scully RE. Malignant lymphoma of the testis, epididymis, and spermatic cord. A clinicopathologic study of 69 cases with immunophenotypic analysis. Am J Surg Pathol 1994;18:376-390.

9. Kemmerling R, Stintzing S, Mühlmann J, Dietze O, Neureiter D. Primary testicular lymphoma: a strictly homogeneous hematological disease? Oncol Rep 2010;23:1261-1267. 